\title{
Basic Principles of Ethics in Javanese-Saivism
}

\author{
$1^{\text {st }}$ Ida Bagus Putu Suamba \\ Department of Business Administration \\ Politeknik Negeri Bali. \\ Badung Indonesia \\ bagusputusuamba@pnb.ac.id
}

ethics have some elements of religious life, and hence ethics become integral part of sadhana (discipline spiritual) in the frame of self-transformation. This proves that the problems of ethics are fundamental in life as virtuous life is considered as gate way to have happiness and consequently vice life should be avoided. The subject for the first time had been dealt philosophically during the period of ancient Greek philosophy in the west, and in texts talk about darsana (philosophy) in Indian tradition; and it continues till present times. Amongst the philosophers, who dealt the problem of morality was Aristotle in his works Nicomachean Ethics and the Politics in which he talks about virtuous and vice life. He reminds us "not in order to know what virtue is, but in order to become good" [2]. In Indian tradition problem of ethics is fundamental and each tradition pays serious attention to this field.

Javanese-Saivism as a philosophical religious tradition in ancient Java $\left(10^{\text {th }}-15^{\text {th }}\right.$ cen. $)$ in the present-day Indonesia is not an exception in this regards [3]. Javanese-Saivism is a unique form/sect of Saiva tradition, which grew and developed in the island of Java (Java-dwipa) having characteristics of Saivism in general. However, it is expressed and concretized in indigenous form of culture of Java. The original seed of Saivism came from India, which is enabling to prove its connection with the other forms of it [4]. It continues to exist as a living tradition in the post Majapahit period in adjacent Bali having acculturation with local culture. In this land, old Javanese traditions like language, religion, philosophy, and culture are preserved and developed for quite long time giving strength or spirit to Balinese literature in following years. This becomes the main core of Balinese religion nowadays despite the fact some changes happen. Owing to this fact, there are some texts written in Balinese or Kawi-Balinese, which elucidate ethical principles even pervading subtly oral traditions. The advancement of this kind of Saivism in Java and continued in Bali was due to the fact that this can adapt various current thoughts prevalent at that times including local culture in addition to a preference of openness of Javanese and Balinese in the encounter with foreign influences. The imprints of it can be seen in both textual and religious traditions up to present times.

This tradition is well-known from ritual and cultural dimensions as tangible things. This form of Saiva tradition has a long ritual tradition practiced by its followers living not only in Bali but in other provinces. Bali-Hinduism as a religious and spiritual tradition exits in Bali may be given various names in the course of time, like "Agama Tirtha", "Siva-Buddha", "Agama Hindu Bali", "Hindu Dharma", and so on is basically further development of Javanese-Saivism, when it is looked at 
from its internal core, viz. metaphysics [5]; and [6] calls it as Balinese Saivism. The grandeur of this tradition can be seen from physical objects in the forms of temple, palace, cave, bathing place, manuscripts, inscriptions, statues, linga, yoni, arts, food, cloth, and culture, etc. spreading over vast areas in Java and Bali; and some other parts of the archipelago. However, ethical principles which are supposed to underline ritual performance have received less even no attention from researcher. Some perhaps regards that ritual can be performed without following ethics as prescribed in textual tradition; rather they interpret it based on modern way of thinking. Modern way of life subtly pervades religious domain, so that many problems happened in terms of modernity versus tradition, the solution offered is through modern approach, which is not always correct. As serious degradation happened of spirituality in massive achievements in materiality of technological society, things like cultural and environmental awareness, loose in relationship amongst member of family or community due to changing in looking at virtues of life; the followers of it use the sources as their guidelines in performing religious or secular actions. There are some indigenous ethical principles, which can be used to lead life and as ethical judgment. Every nation now looks at its ancient tradition and wisdom to face the fast changing of global world. Therefore, study on the principles of ethics as revealed in the literature is worth to be undertaken under the circumstances that any ethical values have emerged from its metaphysics of Javanesesaivism.

This paper attempts to formulate some basic principles of ethics in Javanese-Saivism as revealed in its textual and religious traditions. These principles will be discussed in some lengths and see the connection of each of them in the overall system of ethics. These form a frame work of the system of ethics in this tradition. These principles are considered important as some other ethical principles are perhaps derived from these basic principles.

\section{A. Javanese-Saivism}

In the field of philosophy, Javanese-Saivism is hardly known in the world despite the fact Saivism along with other religious Indian traditions were prevalent in ancient Java. It flourished approximately in $10^{\text {th }}-15^{\text {th }}$ century in Java; and it is well preserved in Bali in the post Majapahit kingdom of EastJava up to present times. Its existence is testified by textual and living traditions taking different forms and expressions encapsulated in local languages and culture. Of this fact, it is a unique school of Saivism differs from others prevalent in India despite of the fact some commonalities exist amongst schools of Saivism. One example of such commonalities is acceptance of linga and yoni images as manifestation of the Lord Siva along with his divine consort Parvati. There were a lot linga and yoni found in Java and Bali. Suamba (2016) have done a pioneering research in this field and investigated its philosophical system based on textual tradition, which differs from other schools of Saivism prevalent in India. It is ... a form of Saivism as it glorifies and worships Lord Siva as the highest principle and other gods emanated from Him as aspects of Him in its system [7]. The characteristics of it, is an amalgamation of various spiritual and religious traditions of Indian origin and indigenous culture. Nonetheless, Siva-Tattva becomes the leading philosophical principle, which brings others working together in one system of religion. The metaphysics (tattva) of this religion is Siva-Tattva, its ethics also uses Siva-Sasana and other sasana texts of saivite in nature [8]. It is further mentioned that in this tradition metaphysics (tattva), ethics (sila/sasana), and ritual (upacara) [9] interwoven into one system in which rituals are outer expressions of faith. People commonly know the religion professed from its outer layers, i.e. ritual in its kinds and complexities; whereas subtle aspect of religion, i.e. metaphysics gets very less attention. For common people ritual is religion; however religion is not always with rituals especially viewed from modern interpretation of religion [10]. As ritual has received more attentions from the masses, ethics becomes very fundamental since ethics gives principles or ideas how a ritual or action should be established with reference to time, place, instruments used, priest, etc. Ethics concerns with good or bad, pure or impure, virtue or vice, etc.

\section{RESEARCH METHOD}

This study uses qualitative approach in design as well as data collection and analysis. The data collected based on library research with specific focus given on ethical values or principles as contained in manuscripts called Sasana texts available in Balinese tradition as the prime sources and supported by living tradition in which those ethical principles are practiced. Since ethical values/principles also inserted in some places in other genres of texts, like poetry (kakawin), like Arjuna-wiwaha, Siwaratri-kalpha, metaphysics (tattva/tutur) like Wrehaspati-tattva, Tattva-jnana, Jnana-siddhanta, prose (parwa), etc., the focus lies on the sasana only to limit the scope of works. There are many texts of ethics known as Sasana written in Sanskrit-Old Javanese and Kawi-Balinese languages available in Bali. To mention some of them are Siwa-sasana, Silakrama-ning-aguron-guron, Wreti-sasana, Brati-sasana, Rsi-sasana, Rajapati-gondala, Sarasamucchaya, Slokantara, Stri-sasana, Putra-sasana, etc. The main subject of those texts can be found in a report of a study of ethical values of Old Javanese literature [11]. Some of them have been translated into English and bahasa Indonesia. These texts are preserved in some public libraries in Bali and abroad, and also as private collection in Bali and Lombok islands. The significant number of sasana texts available comparing to tattva, shows the significant position of ethics have in the overall spiritual pursuit of Javanese. Data were collected from those texts, grouping was done and analysing each of them in connection to importance and significance was attempted.

On reading those texts, the data found are identified, collected, grouped, and analysed in a philosophical way to answer the objectives of the research. Some ethical principles are pointed out and elucidated to see its nature, position, relation with others, and its significance in the spiritual pursuit of seeker. Conclusion was made based on the analysis of the data obtained from those sources. 


\section{RESULT AND DISCUSSION}

\section{A. Position of ethics}

As mentioned above, ethics (sasana/sila/niti-sastra) is a part and parcel of its philosophical and religious systems; it is inseparable and integral part to form a system. It gives up to be called a system of Javanese-Saivism when ethics is absent from its existence. It gives principles of basic ethical values that can be used to evaluate any action either secular or spiritual in nature in the lights of ethical teachings. It is also a guiding principle on how followers should or should not act; which action is injunction and prohibition. Ethics and ritual brings the principles elucidated in metaphysics closer to the world of phenomenon as followers can act or perform the subtle truth of metaphysics through practicing ethics; and express one's religiosity through rituals in everyday life. In other words, the truth contains in metaphysics cannot be implemented without action; and for that ethics is required since it deals with virtues or vice actions; moral action is to be followed or non-moral action to be avoided. Actually it is the truth of metaphysics, which is very subtle and abstract, in action performed by the followers. In this regards we can tentatively say that ethics behaves as a connecting principle which plays its important role between bridging the metaphysics and the world of reality in which action --- be it religious or secular ---is performed. With ethics the follower practice or exercises their faith or belief.

With observing ethics purity of mind and body or microcosm and macrocosm may be secured, and hence ritual/sacrifice may be performed accordingly. Of the three elements, metaphysics, ethics, and ritual or action, the first is the very essence of it, it is subtle and the spirit of all; ethics concerns with goodness or badness, virtue or vice in the domain of action, whereas ritual or action is outer part of the system in which everyone may see, touch since it takes in three dimensions. Materials, means or instruments used in ritual attract people's interest to take part in it. Every one may participate in ritual as a form of faith in the tradition.

Ethics since it concerns with do and don't principles, it is very fundamental in the journey of self in this world. We cannot imagine when no ethics govern human life either spiritual of secular. Or, society will fall to peril or chaos when ethics or morality does not work due to some reasons. No progress happens in spirituality of religion when society is in chaos or damaged psychologically.

The very nature of self is conscious, purity, and happy but in the course of life these states can be hampered by impurities which are the cause of misery or suffers. To discard it, there should be ways, i.e. moral action that may be undertaken by a seeker. It has a must-do principle when one wishes to have spiritual progress in life. Of its position Sarasamucchaya text (slokas 2-4) mentions that amongst creatures born in this world, it is only as a human being who can act good or bad action. It is fortunate to be born as a human being as through performing ethics, one may help himself to lead moral life. Owing to this fact whatever life one has experienced it should not be regretted even though our life is unfortunate, because it is difficult to be born as a human being. To be a human being is excellent because he can help himself from sufferings through performing ethical actions. Ethics, therefore, positions human life as a precious thing; and glorifies its dignity as a pure and happy existence in the world. Sciences have developed very well in this modern time; however they cannot lead human beings to be virtues life.

The diagram below shows tight relationship amongst metaphysics, ethics, and ritual in the system of religion and philosophy of Javanese-Saivism [12]. Reading from outer layer, ritual is another forms of principles believed in metaphysics, it is the most gross element a seeker can see or touch since in its practices involving materials, instruments, images, fire, etc. Next is ethics which is foundation of performing any ritual/action. It teaches to be good and virtuous person because such condition is a prerequisite condition to approach the divinity. Next, metaphysics is the most subtle and abstract that only smart or intellectual person may grasp the ideas/principles. Masses usually perform ritual and follow the ethics; they are not interested in metaphysics.

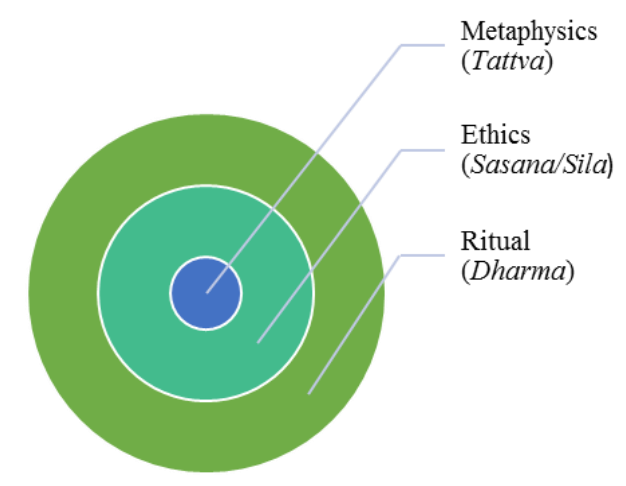

Fig 1: The relation of metaphysics, ethics, and ritual

\section{B. Literature}

Sources of Javanese-Saivism have a wide range of literature on ethics expressed in various modes. Ethical messages may be found in poem literature of various forms (like Siwararikalpha) or in prose forms (like Siwa-sasana). As this tradition is a confluence of various traditions of Indian origin and local culture, its ethics is also received some elements from other traditions like Brahmanism or Vedism, Buddhism, Tantrism, Samkhya, Yoga, etc. These all behave as sources of written and oral traditions like fables, or folklores, or music/songs, arts living in society expressed in local languages. However, we have not yet had a comprehensive list of sasana texts in its developments or cultural map of their spreading. In short we may state that ethics pervades almost all literatures --- be it philosophical in nature as contained in tattva texts, ethics (sasana), or ritual (yajna). All of these are traditionally called sastra as the spiritual sources of the religion.

A group of literature on ethics known as sasana, sila or niti-sastra mainly talks about ethical values or principles of do and don't despite the fact principle of ethics may be found in tattva/tutur and kavya (poetry) texts. Exposition of yoga, e.g. is 
mainly found in tattva texts like in Wrehapati-tattva, Tattvajnana, Ganapati-tattva, etc. To mention just some of sasana texts are Siwa-sasana, Silakrama-ning-aguron-guron, WrtiSasana, Brati-Sasana, Rsi-Sasana, Rajapati-Gondala, Sarasamucchaya, Slokantara, Rsi-Sasana, Stri-Sasana, Putrasasana, etc. [13]. Siva-Sasana consists of the pre-conditions that are to be observed by those who are joining the priesthood life. Vrati-Sasana is for an ascetic. Rsi-Sasana is for hermitage. Sila-Krama is for guru (spiritual-master) and sisya (spiritual disciple). Stri-Sasana is for house wives. Putra-Sasana is for children. Raja Dharma/Rajapati-Gundala is for king, etc. The first three are for the Dvijati, whereas the rests are for common people [14].

These literatures are written in Sanskrit-Old Javanese and Old Javanese (Kawi) language in the form of palm-leaf manuscripts. Some of them perhaps written in Java and the ones belong to Kawi-Balinese literature were written in Bali in post Majapahit period in 15 th century AD. Process of transmission or rewritten in new palm-leaf manuscripts still continues in Bali even in modern times. They have been preserved in Bali and Lombok; and for that roles of brahmins and kings cannot be excluded. Some public libraries in Indonesia and abroad keep them as their collections in addition to private or home libraries in Bali and Lombok islands. Some of them have been rewritten in paper form, translated into Hindi, English, and bahasa Indonesia in modern times. These texts are in used by the saiva followers especially a person belongs to twice-born (dwijati) in practicing religious belief.

\section{Two broad classifications}

Sasana texts address the problems of human sufferings due to wrong or unjust actions (asubha-karma). The literatures can be utilized in helping human being to live morally either as an individual or personal or as a community with its complexities. No other science can lead humans to perform virtues life unless one observes ethical teachings. Advanced society in science and technology is not a guarantee its people observe ethical or virtuous life; rather so many human and environmental problems happen due to violation of ethics, moral, or rules either in developed or undeveloped society. After all, they need guide line or ethical frame work to act meaningfully in society. When unjust, wicked action happens sometimes one is in problem to give justification whether it is right or wrong; or one may not have enough courage to maintain the truth even though one knows the right from the wrong action. Ultimately, non-moral action will bring suffering or hell; on the other hand, moral action will bring happiness.

This problem is caused by inability to control mind (manas) and senses (indriyas) in the pursuit of happiness. Or, they may have wrong ideas on the conception of freedom of happiness that uncontrolled sensual fulfilment can bring real happiness. Fulfilments of sensual enjoyment are not always right ethically. Of this fact, the texts reveal principles of ethics for a particular type person and/or social status of person in the frame of Catur-asrama (four levels/stages of life) and Catur-purusaartha (four goals of life) --- be it holy person, teacher, students, king, husband, wife, children, etc. Some ethical principles may not be matched with one disposition or social status, and hence it requires specific ethics with reference to duty (swadharma) without neglecting common duty (sadharana-dharma). Specific ethics is usually rigorous in nature and only a particular type of person may be able to practice it.

Owing to this varieties, ethical teachings prescribed in the literature may be divided into two broad divisions, viz. ethical values/principles for twice born person (dwijati, sadhaka, wiku, etc.), and ethical values/principles for lay person/commoner in the frame of Catur-asramas (four stages of life). Some texts like Siwa-sasana, Wrti-sasana, Brati-sasana, Silakrama-ningaguron-guron, Rsi-sasana, etc. belong to the sadhaka division; whereas texts like Sarasamucchaya, Slokantara, Rajapatigondala, etc. for lay person [15]. In another place Suamba (2014) mentiones some ethical teachings like A. Tri-kaya parisuddha [three types of purity, viz. mind (manas), words (vak), and action (kaya)]; B. Subha-asubha-karma (good/right and bad/wrong action); C. Yama and Niyama (called Dasa-sila - ten ethical principles); D. Sadangga-yoga (six limbs of yoga, viz. (1) Pratyahara (withdrawal of senses from their objects), (2) Dhyana (meditation), (3) Pranayama (breath control), (4) Dharana (breath holding), (5) Tarka (reflection), and (6) Samadhi (concentration), E. Vrata (vow/fasting), F. Dana (donation), G. Purusartha (goals of life); H. Yajna (sacrifice/ritual), etc. [16]. He further states that the very core of ethical teachings is to obtain purity of mind and body; not only body (microcosm) but also universe (macrocosm) since by nature they are essentially composed of the same elements called five gross elements (bhutas), viz. earth (prthivi), water/liquid (apah), heat/light (tejas), wind (vayu), and ether (akasa). These all have their quality of five subtle elements (tan matra), viz. (1) sound (sabda), (2) touch (sparsa), (3) form (rupa), (4) taste (rasa), and (5) odour (gandha). Human body consists of three layers/elements, viz. gross body (sthulasarira), subtle body (suksma-sarira) and self/soul (antahkarana). For the first two layers/elements are composed of five gross elements (Panca-maha-bhutas) originated from Prakrti (matter principle). They underwent permutation in multifarious ways [17].

As there are some teachings of ethics with respect to stages of life, ethics for lay person is to be practiced first before practicing ethics for sadhaka; it is considered as the base for entering the world of priesthood which is considered tougher. General or common ethical virtues like purity, truthfulness, non-violence, etc. are applicable not only for lay person but also for sadhaka or holy person. It is recommended that ethics of general/common person should be practiced first prior to ethics for priesthood. Since ethics for priest (sadhaka) is tough and details, lay person is not obliged to follow them. A sadhaka will be able to follow the priesthood ethics when he/she is accustomed with general ethical values.

There are a lot of ethical values/principles available in the literature of this tradition which requires further research. The following are some of cardinal ethical values which supposed to be the back bone of ethical system of Javanese-Saivism. 


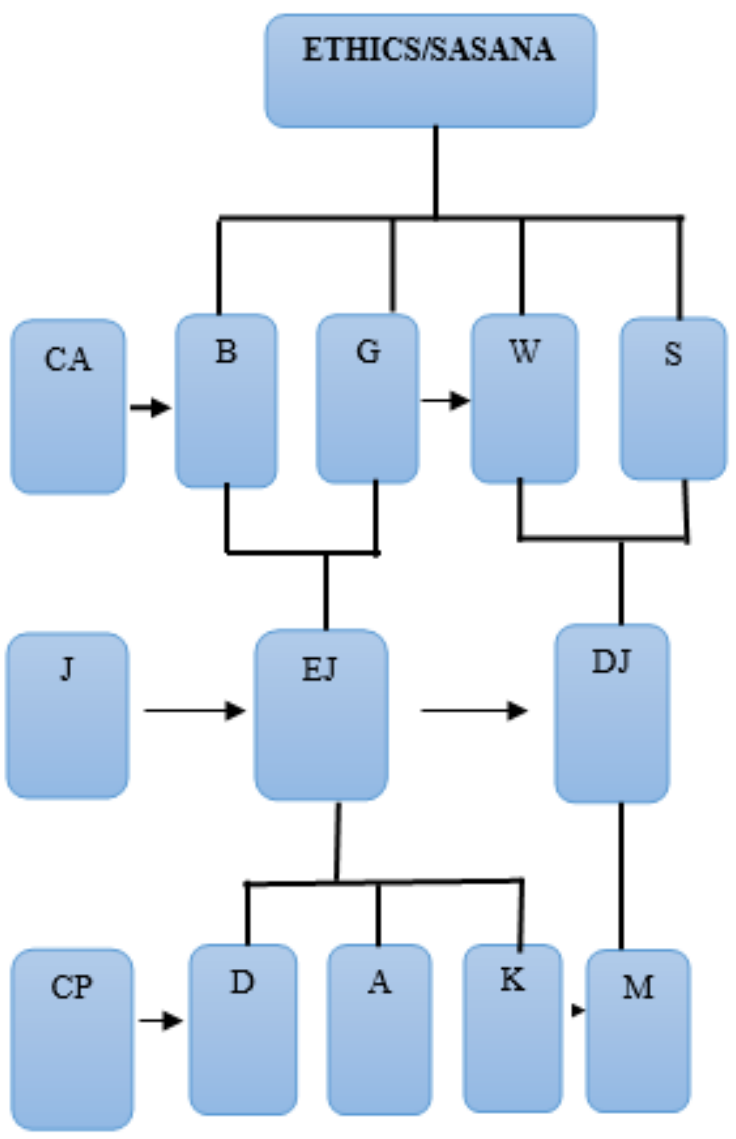

Notes:

CA: Catur Asrama; B: Brahmacarya; G: Grhastha; W: Wanaprastha; S: Sannyasa; J: Jati; EK: Eka Jati; DW: Dwi Jati; CP: Catur Purusartha; D: Dharma; A: Artha, K: Kama; M: Moksa.

Fig 2: Ethics, Catur-Asrama, and Catur-Purusartha

\section{Catur-purusa-artha (four goals of human life)}

The entire human life is viewed as a long spiritual journey in which everyone proceeds from lower to higher level of consciousness till reaching the ultimate goal of life in which union of self and the Supreme Self happens; or the progress happens from demoniac character (asuri-sampada) to godly character (daiwi-sampada) [18]. And, the quality in terms of spirituality is justified based on this condition. Meaningful progress should be attempted, or in other words, meaningless one should be avoided, and for that reason, one should plan life carefully, perform it with awareness and responsibility with the inner attitude of devotion and surrender till union can be achieved with the highest reality as the final or ultimate goal of life---parama-purusa-artha (moksa). In this regards the role of spiritual master (guru) in guiding or supervising a seeker; and environments are important since a guru knows well how to deal the problem. Any action performed in life should be able to bring about some changes for betterment of life which includes physical, intellectual, and spiritual domains. To accomplish in the right direction is not an easy task unless one holds ethics having its base on metaphysics of the system of thought. In each progress one moves from one state/stage to another stage passing various hurdles and opportunities till one achieve his final goal. Of this frame work, there are a lot of desires or goals to be achieved in life either short-term or longterm ones. Some goals are genuine and the others are superficial. Human is sometimes confused to search the superficial rather than the genuine one.

When the fulfilment of desire, lust or senses is to be attempted, there are so many goal of life if every desire is taken into account. Desires are endless while life is limited by place and time. Amongst those unlimited goals, they can be broadly divided into four divisions, viz. righteousness (dharma), wealth/security (artha), desires (kama), and freedom/emancipation (moksa). The attempts require progressive movement from dharma till moksa, since dharma is the foundation for the achievement of the other three goals. These goals are attempted progressively in stages of life known as four stages of life (Catur-Asrama), viz. Brahmacarya, Grhasta, Wanaprastha, and Sanyasa. Dharma is the pursuit in the period of Brahmacarya, Artha and Kama are pursuits in the period of Grhastha, and Moksa is the pursuit in the period of Wanaprastha and Sanyasa. Irrespective of their significance, dharma is put at the very beginning of pursuit and at the same times pervades the others. The concept of dharma must be understood well, otherwise, life will terminate in perils. When one holds dharma in faith and devotion, the dharma itself protects and saves (dharma raksati raksita) him as stated in Dharma-sastra.

Dharma in Indian tradition has been interpreted in various ways in various traditions - be it in Brahmanic or Sramanic tradition. Accordingly, there are various meanings of dharmadhamma available laboured by thinkers, philosophers, or religious leaders as depicted in various literatures. Not only in the Indian sub-continent, dharma-dhamma becomes the most important cardinal values on which oriental culture has been developed to its best [20]. As underlying and substratum principles of the world, Dharma may be used in metaphysics, ethics, and ritual. However, none can define dharma in a comprehensive way since dharma behaves as the very nature, foundation, and existence of the humanity and the world. Javanese literature especially of ethics understands it as ethics, moral, norm, rules, regulation, or law that governs human life. It is cosmic law which governs all existence in the world. Dharma along with its opposite adharma is often used to express the truth or ethical virtues or vice. This implies that one has an option in life whether to lead life in moral action or otherwise; and the literature gives the result of any action performed. Dharma has been given serious attention in the frame of Catur-purusa-artha. It is so unless the foundation should be built, the entire system will be collapse. Dharma is positioned as the very first and basic to be acquired prior to other fulfilments. Thus, dharma is the first goal that should be achieved irrespective its vast coverage.

Sarasamucchaya (sloka 12) mentions that any fulfilments of possession/wealth (artha) and desires/lust (kama) will be futile unless it is acquired based on dharma, on the contrary, 
when one is done based on adharma, the result for the long run will be suffer or hell. This text compares dharma with way to heaven; it is like boat as a means for a merchant to cross the ocean (sloka 14). Like movement of the Sun which can discard darkness of the world, similarly one who has performed dharma, he/she can vanish all kinds of sin (dosa) (sloka 16). It further states that the excellence of dharma is as source of happiness (sukha) for those who have performed it. Dharma behaves as protector/shade for knowledge person; it is only dharma can defuse sins of the three world (tri-lokas) (sloka 18) [21]. Even though its significance is elucidated in beautiful way, to perform dharma sincerely is not always easy; it requires a burning spirit to hold the dharma in every place and condition. A weak person will be easily change his mind and divert his attention to adharma, because he thinks that apparently dharma give suffering whereas adharma gives enjoyment. Uncheck fulfilment of senses give enjoyments.

Dharma is interpreted as ethical virtues that are worth to observe. Text of Wrti-sasana (sloka 22) mentions ten ethical virtues (Dasa-dharma), viz. dhreti (purity of mind), viz. ksama (patience), dama (remembering cleanness of mind), steya (non-stealing), soca (cleaning self with ash---bhasma), indriyani graha (controlling desires/lust), hrih (embarrassed), widya (studying knowledge), satya (truthfulness), and akrodha (not angry) that can purify oneself [22]. With this fact dharma is not only used to refer to metaphysical principles, $r t a$, law, norms, or regulation but also ethics which deals with action. Thus, dharma pervades and penetrates all existences.

\section{E. Purity (nirmala) vs impurity (mala) and the role of mind (manas)}

The motif of the followers to observe ethical teachings is securing purity (purity) of mind (citta), words/utterance (wak), and actions (kaya)---known as Tri-kaya [23]. for higher state of humanity. Purity is the pre-condition for attainment of Samadhi [24]. As soul entangled with impurity, purity is not given by any agencies but it should be attempted sincerely through virtuous life. Ethical teachings whatever simple they are should be attempted with sincerity and humble. Spiritual knowledge (jnana) can only be grasped after purity of Tri-kaya is obtained. Under the supervision of a spiritual master (guru), one is supposed to have some progresses in the path of spirituality. Gradual development of purity of one's disposition is possible to be achieved by habitual action for which hindrances on this path is sometimes unavoidable. It implies that in using ethical principles one tries to control over mind, words, and actions. Accordingly, one will try to avoid or discard from state of impurity (mala) either of the Tri-kaya or environments. Ethically there are some ethical ways suggested to be attempted in daily life, e.g. purity (sauca) as ethical virtue should be attempted perhaps gradually in conducive environment. Impurity hampers path of righteousness.

By nature everyone born is pure. As one grows up on which environment starts influencing him, mind starts creating ethical problems. Due to the operation of mind as the chief of senses (indriyas), one may be attached by impurity of mind, words, and action. It is mentioned in Sarasamucchaya (sloka
80) that the reason it is called mind (manah) is because it is the source of lust; it causes to act good and bad actions as well. Therefore, mind should be soon controlled [25], otherwise will endanger the mind itself. To purify them is attempted through conducting action taught in the ethical teachings. In Sila-krama text it is mentioned that body is purified by water, mind is purified by truthfulness, self is purified by knowledge and penance (tapa), and intellect is purified by wisdom. Truthfulness cannot only purify mind but also words and actions. From this fact, it can be seen that purifying by using physical object/instrument is only for physical body; for subtle bodies or self (atma) is through controlling Tri-kaya. It is obvious here that purifying subtle bodies is more difficult than corporal body. And further it requires strategies to cope with the problems.

Purity become more important based on the opinion that the highest principle, which is in the state of purity, can only be approached by devotees through purity. As Patanjali proposed in his Yoga-sutra that the ultimate objective for practicing Astanga-yoga is to secure pure and controlled mind since it is in the state of equipoise stable pure, mind can reflect the reality as it is like the ground of pond can be clearly seen when the water is pure, clean, and stable. The source by which one is attached by impurity is mind (manah) since it is only faculty of cognition but also of conation. In here is the place of discriminative knowledge (viveka-jnana) obtained after process of acquiring knowledge is completed. There is always a process of forming some knowledge based on the stimuli or information given by each senses. Since the involvement of I-ness/ego, knowledge becomes subjective; and considered it has higher position. Manah is a place of battle place where tri-guna, viz. satvam, rajas, and tamas; and ego (ahamkara) fighting each other, each wants to be dominant over the others.

Life is often viewed as a long spiritual journey with definite terminal point. Everyone is expected to proceed to higher state of manhood; but many of them are going back to state of impurity due to unable to protect or maintain it. Selfish fulfilment of senses will lead one to impurity because it is done devoid of lights of dharma. Self-transformation can only be experienced when one performs ethics; and for this necessity, the role of a spiritual master (guru) is significant. Since every one tends to be lazy in performing ethics as senses always needs fulfilments, awareness of the importance of good or virtues, habitual action (abhyasa) is much demanded. It is basically the foundation of discipline spiritual (sadhana) for higher spiritual state.

This shows that this tradition considers ethics is fundamental in spiritual ascendance no matter for priest or lay person. Quality of being a spiritual is based on his purity (sauca) of body and mind. Of this fact, yoga has its foundation on purity as ethical virtues amongst ten cardinal ethical values --Dasa-silas that should be attempted by those who are in spiritual life. Purity of body and mind should be secured first through observation of ethics. In here lays strategic position of fasting (vrata) as a means to discipline or culture mind and body. 


\section{F. Karmapatha: controlling indriyas}

As a form of evolute (tattva) in Saivism, senses (indriyas) are closed to external world since with the fulfilment, the self has an access to external world and at the same time get attached with impurity of it provided that the fulfilment is unchecked or imbalance. By nature all senses need to be satisfied with respective objects of enjoyments, and hence they pull the self to external world on which peaceful or standstill mind is difficult to achieve. Indriya a subtle principle in oneself has a corresponding place or point (called golaka) through which a respective sense may be satisfied. There are ten in number and hence they called ten senses (Dasendriyas), and accordingly there are ten Golakas. For Chaksu-indriya its location is on eyes, Srotendriya is on ears, Jihwendriya is on tongue, Granendriya is on nose, Twakindriya on skin, etc. Under the command of mind (Manas) all senses can perform each function in a respective way in human life. Being conscious and pure, the faith of self (atma) depends of the senses under the leadership of mind (manas). The problem for mind is that it should control itself an entity in the state of flux of Tri-guna and Ahamkara.

Fulfilling senses (indriyas) is the problems of controlling the senses. It lies in between fulfilment of senses and selfmortification. It is a moderate position in which the role of mind as a controller becomes very important. Senses are parts and parcels of human nature. None can live normally without the presence of senses and their fulfilments. In spiritual journey, it should not be oppressed till zero fulfilments even destroy it, rather to fulfil it in a proportional way with reference to age or physical and psychological circumstances. The operation of indriyas indicates progress of life. The problem comes when fulfilment of senses just for the senses themselves rather for their operation bases on higher goal of life. Senses operate in the domains of artha and kama---in the frame of Catur-purusa-artha, viz. Dharma, Artha, Kama, and Moksa.

Text of Sarasamucchaya introduces the concept of Karmapatha [26], a way to control body, words, and mind. In Sarasamucchaya (sloka 74), it mentions that karmapatha is basically the way how to control senses (indriyas) of ten in numbers that is proper to be followed. The descriptions are like these. Movement of mind consists of three parts; movement of words consists of four parts, and movement of action consists of three parts. Thus, there are ten actions which are originated from body, words, and mind. That is proper to be paid attention to [27]. In slokas 75 and 76 the text elucidates each part of them. Movement of mind consists of three parts, viz. not willing and jealous with possession of other, not having rude attitude to other creatures, belief in the teaching of karmaphala (cause and effect); movement of words consists of four parts, viz. wicked words (pratyakenya), rude words (aprgas), words of defamation (pisuna), and lie words (mitya); and movement of action consists of three parts, viz. killing (syamatimati), stealing (mangahalahal), and illegal sexual act (si paradara). Because one is well-known is due to his action, mind, and words. That is interesting for man to know the personality of one. Therefore, the good thing should be habituated in action, words, and mind (ngabyasan ring kaya, wak, manah ) [28].This means that the final achievement is not achieved by accidental or chance but by gradual progress from lower to higher state of purity or consciousness.

\section{G. Prohibition and injunction}

With reference to the intention of the messages, ethical teachings can be broadly divided into two divisions, viz. (1) prohibition, i.e., action to be avoided, and (2) injunction, i.e., action obliged to be performed. Some actions are prohibited because, if they are performed, will cause sufferings or hell (naraka). On the contrary, some actions are suggested or advised to be done because they can lead one to happiness or heaven (swarga). These teachings happen in plenty number in our sasana texts. Having a position of the highest reality, the teachings imparted are words of the highest reality and it is obliged to be done by the seeker. Of these two big divisions, the tradition is rich and elucidated in various forms of expressions. Yama, e.g. belongs to prohibition; whereas Niyama belongs to injunction [29]. Something prohibited will terminate in goodness, on the other hand, when ethical teaching is broken or acted out, one will terminate in badness. Since it is not easy to be habitual with goodness, one should find conducive environment where goodness may develop to its best state. Since goodness and badness are present in some degrees in human life, one should be able to manage these and can transcend them to higher level of consciousness.

Human beings are between these two poles of actions. Sometimes they are not sure either one action done belong to injunction or prohibition; moreover one does not have discriminative knowledge. It is very hard to avoid the something bad happened. This becomes pertinent in the materialistic pursuit which causes one going away from purity of spirituality. Owing to this fact, one is supposed to have a pertinent principle of ethics which can be used to lead life morally since by nature everyone is morally born. When it is clear in mind, one can decide which action is to be performed or avoided.

\section{H. Subha vs. Asubha karma [moral vs. non-moral action]}

In general actions can be divided into two broad divisions, viz. moral vs. non-moral action [Subha- vs. Asubha-karma]. By nature every human born wishes to be a good person, but due to some reasons, one may turn to be a bad person. The tradition seems to accept that the ethical values/principles is based on ideas underlining action not on result. Even though the consequence or effect resulted from an action is good, but it cannot be accepted when the ideas or procedures undertaken is adharmic. Intention or ideas is the determiner of an action whether good or bed action. In the teachings of Tri-kaya, viz. manacika, wacika, and kayika the seed lays on the mind (manah). It is the controller of all desires or senses. Result as a consequence of intention cannot be used to justify an action which is morally right. The things which make them different are the motifs which underline the actions. When an action is performed based on adharma, it belongs to Asubha-karma, and the result/effect/fruit as the consequence of action performed is finally sufferings or hells (naraka). On the other hand, if the action is performed based on dharma (righteousness), the result 
will be happiness or heaven (swarga). It looks like the conception of ethical virtues of Aristotle of ancient Greek.

The literatures of Javanese-Saivism give a lot of explanations or examples of these two cardinal values, right vs. wrong in various ways or modes of expression. Almost all art forms created contain message of ethical values. In epic literatures these values are exemplified by actors of a play so audience can see clearly the principles underlying the action performed.

\section{Dasa-Sila (ten cardinal ethical principles)}

One of important ethical virtues is Dasa-sila (ten cardinal ethical principles), which consists of five Yama (Panca-YamaBrata) and five Niyama (Panca-Niyama-Brata). Yama is considered as the foundation for the performance of Niyama. This regards the performance of these are forms of penance (vrata) that are directed for the attainment of purity of mind and body in the path of self-transformation. It is so since to have purity, one should try to practise and feel the truth. These ethical values are silas (foundation) for yoga in line with Yogasutra of Patanjali. Text of Wrti-sasana (sloka 2) states that due to performing Yama and Niyama, one will achieve pure intellect (apan yang karaksa yama niyama brata, tan cala buddhi) [30]. Yama consists of ahimsa, brahmacarya, satya, avyavaharika, and asteya. (1) Ahimsa means not killing. (2) Brahmacaryya means celibacy and keen on learning mantra of brahmancari-hood. (3) Satya means saying truthfulness. (4) Awyawaharika means is not attached with worldly affairs; and (5) Astenya means not to have possession of other, non-stealing [31]. The slokas elucidates each part of Yama-Brata. In these series, ahimsa is taken as the corner stone for observing virtues life.

Niyama-Brata consists of five elements, viz. akrodha, guru susrusa, soca, aharalaghava, and apramada. (1) Akrodha means is not controlled by angriness, (2) guru susrusa means always close to a spiritual master (guru) to follow his instructions and respect him, (3) soca means always cleans his body and spirit, and begging purification from the Lord, (4) aharalaghawa means taking food carelessly; and (5) apramada means not doubtful to perform duty of priesthood [32].

In the texts of Wretti-Sasana and Sarasamucchaya (slokas: 268-270), each Niyama and Yama are developed it into ten of each Yama and Niyama respectively, so that twenty in totality. Ten Yama: (1) Ansesangsia means does not expects respect from society, (2) Ksama means putting priority on patience, (3) Satya means not deceitful, (4) Ahingsa means not killing, (5) Dama means not arrogant, (6) Sarjjawa means having noble personality, (7) Dhyana means always concentrating on the form of god, (8) Prasada means loves people, (9) Madhurya means ability in uttering words and shows nice personality, and (10) Mredhuta means tenderness. These are all called Yama [33]; whereas ten Niyamas are as follows (1) Sauca means always keep body and mind clean, pure, (2) Ijya means always praising, (3) Tapa means controlling body and senses, (4) Dana means to donate, (5) Swadhyaya means retelling what has been achieved from learning, (6) Upasthanigraha means lessening desire of eating, (7) Brata means not eating meat and the like, (8) Upawasa means fasting, (9) Mauna (speechless), and (10) Snana (always cleaning body with water [34].

With this fact, we have not only ten Dasa-silas, but we also have Dwadasa-sila, which consist of ten Yamas and Niyamas. This was perhaps due to the importance of ethical teachings everyone thinks of it in self-transformation.

\section{CONCLUSION}

Javanese-Saivism as a system of philosophy and religion has ethical values/principles as contained in its literature in addition to rituals; it is a part of its system of philosophy. Metaphysics, ethics, and rituals---called Tri-Dharma are inseparable elements and each of them connected to the other having the core on metaphysics as the store house of principles; manifested in ethics and rituals by the followers. The absence of any of them will cause defect as a system of philosophy and religion. It has centrality in the belief on the highest reality whose nature is consciousness, purity, and happiness. Those goals as formulated in Catur-Purusartha can only be achieved when one performs ethical teachings sincerely. It is a religion in which philosophy is put in action either in ethics or rituals. Through ethics a seeker is directed to a right path of action. Ethics is manifested based on the principles believed in metaphysics, and further rituals are outer expression of seeker showing his faith or religiosity. Ethics and rituals performed to achieve these states, and hence ethics is very fundamental in the journey of self.

With reference to social status of the followers, broadly speaking its ethics are two kinds, viz. one is addressed for twice-born (dwijati) group; and the other one is for lay persons (eka-jati), which are again classified into some kinds of person according to one's social status, disposition or duty (swadharma). These are reflected in the textual traditions. However, common ethics is regarded as the base on which ethics of dwijati may be performed after one is converted his social status from eka-jati to dwijati through a series of rituals. There are texts which discusses ethical principles known as Sasana/Niti-sastra despite the fact ethical values pervade almost all literatures. This shows that Javanese stalwarts in ancient Java were very keen in spiritual pursuit. The literatures recorded their dynamic as a form of spiritual quests. Anyway, ethics was given a serious attention reflected in plenty number of texts.

There a lot of ethical values, principles available in this system as reflected in its literature. Amongst them are the concepts of dharma, catur purusa artha, catur asrama, purity, tri-kaya, karmapatha, asubha-subha-karma, yama-niyama, yoga, and moksa. They are essential features of its ethical system. Each of them is connected in some ways, and the performance of each of them aiming at self-transformation; and regarding life as a spiritual journey to within. All kinds of 
desires that are to be satisfied should be attempted based on dharma (righteousness).

Ethics plays very important role in life either secular or spiritual since if it is performed sincerely, it leads one to progress in a positive way. Success in spiritual life is not given by any agency or god, but it should be attempted under the supervision of spiritual master (guru) and supported by a positive environment. Ethics in the course of life should be habituated with a burning spirit that betterment in any plane of life can only be achieved when people observe moral life, not vice versa.

\section{ACKNOWLEDGMENT}

The author would like to thank authority of the Centre of Research and Community Services of Politeknik Negeri Bali for supports to participate sessions in the IJCST conference 2018; and thank to the committee of the conference for accepting my paper to be presented in this academic event.

\section{REFERENCES}

[1] T.Z. Lavine, From Socrates to Sartre: the philosophic quest, Bantam Books, New York, 1984, p. 45.

[2] Robert Audi (ed.), The Cambridge dictionary of philosophy; Cambridge University Press, Cambridge, 2nd ed., 1999, p. 50.

[3] IBP. Suamba, and I G Mudana, 2017, 'Times in rituals of JavaneseSaivism', IOP Publishing IOP Conf. Series: Journal of Physics: Conf. Series 953, p.1.

[4] IBP. Suamba, Javanese-saivism: a philosohical study of tattva texts, BR Publishing Corporation, New Delhi, 2016, p. 14.

[5] IBP. Suamba, and I G Mudana, 2017, 'Times in Rituals of JavaneseSaivism', IOP Publishing IOP Conf. Series: Journal of Physics: Conf. Series 953, p.1.

[6] L.E Nelson "Is god good? Aquinas, Samkara, Abhinavagupta, Balinese Saivism, and the Problematic of the Argument from Evil," Journal of Hindu-Christian Studies, Vol. 29, 2016; Article 3, p. 1, available at: https://doi.org/10.7825/2164-6279.1626 retrieved on 27 August 2018.

[7] IBP.Suamba, Javanese-saivism: a philosohical study of tattva texts, BR Publishing Corporation, New Delhi, 2016, p. 14.

[8] IBP. Suamba, and I G Mudana, 2017, 'Times in Rituals of JavaneseSaivism', IOP Publishing IOP Conf. Series: Journal of Physics: Conf. Series 953, p.1.

[9] IBP.Suamba, Javanese-saivism: a philosohical study of tattva texts, BR Publishing Corporation, New Delhi, 2016, pp. 14, 296.

[10] IBP. Suamba, and I G Mudana, 2017, 'Times in Rituals of JavaneseSaivism', IOP Publishing IOP Conf. Series: Journal of Physics: Conf. Series 953, p.1.

[11] IBP. Suamba and IB Artha Adnyana, Etika dalam susastra jawa kuno: studi filsafat agama hindu atas naskah-naskah sasana/niti-sastra, Laporan Penelitian Unggulan Perguruan Tinggi, Pusat Penelitian dan Pengabdian kepada Masyarakat Politeknik Negeri Bali, 2012b, Denpasar.

[12] IBP.Suamba, Javanese-saivism: a philosohical study of tattva texts, BR Publishing Corporation, New Delhi, 2016, p. 75; IBP. Suamba, "Ethics and Ritual and their Impacts on Culture of Javanese Saivism"in International Journal of Multidisciplinary Education Research, Vol. 3, Issue 1 (1), 2014, pp. 8-21.

[13] IBP. and IB. Artha Adnyana, Etika dalam susastra jawa kuno: studi filsafat agama hindu atas naskah-naskah sasana/niti-sastra, Laporan Penelitian Unggulan Perguruan Tinggi, Pusat Penelitian dan Pengabdian kepada Masyarakat Politeknik Negeri Bali, 2012, Denpasar.
[14] IBP.Suamba, Javanese-saivism: a philosohical study of tattva texts, BR Publishing Corporation, New Delhi, 2016, p. 47.

[15] [IBP. Suamba, Javanese-saivism: a philosohical study of tattva texts, BR Publishing Corporation, New Delhi, 2016, p. 47.

[16] IBP. Suamba, "Ethics and Ritual and Their Impacts on Culture of Javanese Saivism"in International Journal of Multidisciplinary Education Research, Vol. 3, Issue 1 (1), 2014, pp. 8-21. www.ijmer.in

[17] IBP. Suamba, "Ethics and Ritual and their Impacts on Culture of Javanese Saivism"in International Journal of Multidisciplinary Education Research, Vol. 3, Issue 1 (1), 2014, pp. 8-21. www.ijmer.in

[18] IBP.Suamba, Javanese-saivism: a philosohical study of tattva texts, BR Publishing Corporation, New Delhi, 2016, p. 58.

[19] IBP.Suamba, Javanese-saivism: a philosohical study of tattva texts, BR Publishing Corporation, New Delhi, 2016, pp. 49, 63.

[20] IBP. Suamba, 'Dharma-dhamma as Ethical Virtues in Sarasamuccaya and its Relevance to the Present-day in Indonesia' (paper) presented in the International Conference on Dharma-Dhamma" held on 21st-23rd September 2012 in Bhopal/Sanchi, Madhya Pradesh, India, p.1.

[21] I Nyoman, Kadjeng, et.al., Sarasamuccaya dengan teks bahasa Sanskerta dan Jawa kuno, Paramita, Surabaya, 1997, pp.15-18; Raghu Vira, Sarasamuccaya: a classical Indonesian compendium of high ideals. International Academy of Indian Culture, New Delhi, 1962, pp. 12-18).

[22] IBP. Suamba and IB. Artha Adnyana, Etika dalam susastra jawa kuno: studi filsafat agama hindu atas naskah-naskah sasana/niti-sastra, Laporan Penelitian Unggulan Perguruan Tinggi, Pusat Penelitian dan Pengabdian kepada Masyarakat Politeknik Negeri Bali, Denpasar, 2012b.

[23] IBP. and IB. Artha Adnyana Etika dalam susastra jawa kuno: studi filsafat agama hindu atas naskah-naskah sasana/niti-sastra, Laporan Penelitian Unggulan Perguruan Tinggi, Pusat Penelitian dan Pengabdian kepada Masyarakat Politeknik Negeri Bali, Denpasar, 2012b., p. 41.

[24] IBP.Suamba, Javanese-saivism: a philosohical study of tattva texts, BR Publishing Corporation, New Delhi, 2016, p. 59.

[25] I Nyoman, Kadjeng, et.al., Sarasamuccaya dengan teks bahasa Sanskerta dan Jawa kuno, Paramita, Surabaya, 1997, pp.66-67.

[26] IBP. Suamba and IB. Artha Adnyana, Etika dalam susastra jawa kuno: studi filsafat agama hindu atas naskah-naskah sasana/niti-sastra, Laporan Penelitian Unggulan Perguruan Tinggi, Pusat Penelitian dan Pengabdian kepada Masyarakat Politeknik Negeri Bali, Denpasar, 2012b, p. 115],

[27] I Nyoman, Kadjeng, et.al. Sarasamuccaya dengan teks bahasa Sanskerta dan Jawa kuno, Paramita, Surabaya, 1997, p.62).

[28] I Nyoman, Kadjeng, et.al., Sarasamuccaya dengan teks bahasa Sanskerta dan Jawa kuno, Paramita, Surabaya., 1997, pp.62-63.

[29] IBP.Suamba, Javanese-saivism: a philosohical study of tattva texts, BR Publishing Corporation, New Delhi, 2016, pp. 55; 69].

[30] IBP. Suamba and IB. Artha Adnyana, Etika dalam susastra jawa kuno: studi filsafat agama hindu atas naskah-naskah sasana/niti-sastra, Laporan Penelitian Unggulan Perguruan Tinggi, Pusat Penelitian dan Pengabdian kepada Masyarakat Politeknik Negeri Bali, Denpasar, 2012b, p. 51.

[31] IBP.Suamba, Javanese-saivism: a philosohical study of tattva texts, BR Publishing Corporation, New Delhi, 2016, p. 55; IBP. Suamba and IB. Artha Adnyana, Etika dalam susastra jawa kuno: studi filsafat agama hindu atas naskah-naskah sasana/niti-sastra, Laporan Penelitian Unggulan Perguruan Tinggi, Pusat Penelitian dan Pengabdian kepada Masyarakat Politeknik Negeri Bali, Denpasar, 2012b, p. 52.

[32] IBP. Suamba, Javanese-saivism: a philosohical study of tattva texts, BR Publishing Corporation, New Delhi, 2016, p. 55; IBP. Suamba and IB. Artha Adnyana, Etika dalam susastra jawa kuno: studi filsafat agama hindu atas naskah-naskah sasana/niti-sastra, Laporan Penelitian Unggulan Perguruan Tinggi, Pusat Penelitian dan Pengabdian kepada Masyarakat Politeknik Negeri Bali, Denpasar, 2012b., p. 52.

[33] IBP. Suamba and IB. Artha Adnyana, Etika dalam susastra jawa kuno: studi filsafat agama hindu atas naskah-naskah sasana/niti-sastra, Laporan Penelitian Unggulan Perguruan Tinggi, Pusat Penelitian dan Pengabdian kepada Masyarakat Politeknik Negeri Bali, Denpasar, 2012b, p. 74.

[34] IBP. Suamba and IB. Artha Adnyana, Etika dalam susastra jawa kuno: studi filsafat agama hindu atas naskah-naskah sasana/niti-sastra, Laporan Penelitian Unggulan Perguruan Tinggi, Pusat Penelitian dan Pengabdian kepada Masyarakat Politeknik Negeri Bali, Denpasar, 2012b, p. 73. 